\title{
A new species of Cincticostella (Ephemeroptera, Ephemerellidae) from China
}

\author{
Chonlakran Auychinda ${ }^{1}$, Dávid Murányi ${ }^{2,3}$, Weihai $\mathrm{Li}^{4}$, Michel Sartori ${ }^{5,6}$, Jean-Luc Gattolliat ${ }^{5,6}$ \\ 1 Animal Systematics and Ecology Speciality Research Unit (ASESRU), Department of Zoology, Faculty of Science, Kasetsart University, \\ Bangkok 1090, Thailand \\ 2 Department of Zoology, Eszterházy Károly University, Leányka u. 6, H-3300 Eger, Hungary \\ 3 Department of Zoology, Hungarian Natural History Museum, Baross u. 13, H-1088 Budapest, Hungary \\ 4 Department of Plant Protection, Henan Institute of Science and Technology, Xinxinag, Henan 453003, China \\ 5 Museum of Zoology, Palais de Rumine, Place Riponne 6, CH-1005 Lausanne, Switzerland \\ 6 University of Lausanne (UNIL), Department of Ecology and Evolution, CH-1015 Lausanne, Switzerland \\ http://zoobank.org/5C92D79F-984A-4465-844E-C0E08B41E903 \\ Corresponding author: Jean-Luc Gattolliat (jean-luc.gattolliat@vd.ch)
}

Academic editor: Stefan Schmidt • Received 29 January 2020 • Accepted 30 March 2020 • Published 16 June 2020

\begin{abstract}
Cincticostella tornata, a new species of Ephemerellidae, is described from China. It belongs to the insolta-species group and is closely related to $C$. femorata. It is hitherto only known from its type locality in central China, more than $1000 \mathrm{~km}$ northern to the known distribution of $C$. femorata. In addition, the COI barcode of the new species is provided.
\end{abstract}

\section{Key Words}

Cincticostella femorata, Cincticostella tornata, COI, mayflies

\section{Introduction}

Cincticostella was established by Allen (1971) as a subgenus of Ephemerella Walsh, 1862, then raised to the generic level the following year (Tshernova 1972). It currently encompasses 17 valid species (Kluge 2019). They are distributed in eastern Palearctic and Oriental regions, including China, India, Japan, Nepal, Thailand and Vietnam. In China, nine species were until now reported: C. colossa Kang \& Yang, 1995, C. elongatula (McLachlan, 1875), C. femorata (Tshernova, 1972), C. fusca Kang \& Yang, 1995, C. gosei (Allen, 1975), C. insolta (Allen, 1971), C. levanidovae (Tshernova, 1952), C. nigra (Ueno, 1928), C. orientalis (Tshernova, 1952) ) (Xie et al. 2009). The larvae can be identified by having the pronotum with a prominent anterolateral projection, the mesothorax with a pair of large wide anterolateral processes, abdominal tergites with paired dorsal tubercules and lamellate imbricate gills on segments III to VII (Allen 1971; 1975). Allen (1975) divid- ed Cincticostella in two species groups: the insolta-group and the nigra-group. The insolta-group is characterized by suboccipital head tubercles and the mid and hindfemora enlarged with characterized protuberances, so-called chalazae (Jacobus and McCafferty 2008). A new subgenus of Cincticostella, Rhionella Allen, 1980, was subsequently established for this species-group (Allen 1980). Jacobus and McCafferty (2008) recognized the monophyly of this species-group, but they considered Rhionella as strict synonym of Cinsticostella to avoid rendering the rest of Cincticostella paraphyletic. In his non-ranking phylogeny of Ephemeroptera, Kluge (2004) still considered Rhionella as valid and Cincticostella as a "plesiomorphon", i.e. a taxon only defined by plesiomorphies.

Cincticostella femorata (Tshernova, 1972) was originally described from Vietnam based on a single larva. It was assigned to Asiatella Tshernova, 1972, but was transferred to Cincticostella as addendum in the same article (Tshernova 1972). This species appears highly de- 
rived within the insolta-group as the mid and hind femora are greatly flattened with strong chalazae on dorsal and sometimes ventral margins, and the prothorax is much broader than in related species. A closely related species, Cincticostella boja (Allen, 1975) was subsequently established for larvae from Thailand, described and figured but unnamed by Gose (1969). The description was just translated from Gose (1969), and no material was examined by Allen (1975). He considered that C. boja was significantly different from other species and especially from $C$. femorata by the quadrangular head, the presence of paired submedian tubercles on tergites II to $\mathrm{X}$ and the well-developed posterolateral projections on segments VII to IX (Allen 1975). Jacobus et al. (2005) examined five larvae from three different Thai localities. They compared the main morphological characters used by Allen (1975), as well as the number of denticles on claws and the relative density of hair-like setae on the caudal filaments and concluded that all specimens present important but intraspecific variations. They consequently considered $C$. boja as a junior synonym of $C$. femorata (Jacobus et al. 2005). Comparisons of original illustrations and descriptions of the two species as well as more recent illustrations of specimens attributed to C. femorata from China (Xie et al. 2009) and Thailand (Martynov et al. 2019) challenged this synonymy. The species is now considered as occurring in Vietnam, Thailand and China (Martynov et al. 2019; Xie et al. 2009).

We had the opportunity to examine material recently collected in China by two of us (DM and WL). Despite important similarities with C. femorata, part of the characters did not match the original and subsequent descriptions of the species. We therefore consider that this material belongs to a new species. The description of this new species may help to better understand the intra- and interspecific variability within $C$. femorata; in the future $C$. femorata may appear as a complex of closely related species.

\section{Material and methods}

\section{Collecting}

The specimens were collected with small sized aquatic net, during a field trip primarily focused on collecting Plecoptera. They were fixed in $75 \%$ ethanol on the field. Holotype and paratypes are kept in the MZL (Museum of Zoology, Lausanne, Switzerland), one paratype in the HNHM (Hungarian Natural History Museum, Budapest, Hungary), one paratype in HIST (Henan Institute of Science and Technology) as indicated in the text.

\section{Morphological examination}

All dissected specimens were entirely mounted on slides in Euparal medium. Drawings and pictures of body parts were made using an Olympus BX51 stereoscopic microscope with a camera lucida or a digital camera Olympus
SC50. Extended depth of focus images were obtained using the software Stream Basic 1.9.4. Pictures of the whole larval body were taken with the Visionary LK system (Dun., Inc., USA). Pictures and drawings were subsequently enhanced with Adobe Photoshop CC2015.

\section{Genetics}

DNA of part of the specimens was extracted using non-destructive methods allowing subsequent morphological analysis (see Vuataz et al. 2011 for details). We amplified a $658 \mathrm{bp}$ fragment of the mitochondrial gene cytochrome oxidase subunit 1 (COI) using the primers LCO 1490 (GGTCAACAAATCATAAAGATATTGG) and HCO 2198 (TAAACTTCAGGGTGACCAAAAAATCA) (Folmer et al. 1994). The polymerase chain reaction was conducted with an initial denaturation temperature of $98{ }^{\circ} \mathrm{C}$ for $30 \mathrm{sec}$ followed by a total of 37 cycles with denaturation temperature of $98{ }^{\circ} \mathrm{C}$ for $10 \mathrm{sec}$, an annealing temperature of $50{ }^{\circ} \mathrm{C}$ for $30 \mathrm{sec}$ and an extension at $72{ }^{\circ} \mathrm{C}$ for $30 \mathrm{sec}$, final extension at $72{ }^{\circ} \mathrm{C}$ for $2 \mathrm{~min}$. Sequencing was done with Sanger's method (Vuataz et al. 2011). The genetic variability between specimens was estimated using Kimura-2-parameter distances (K2P), calculated with the program MEGA 7 (Kumar et al. 2016).

\section{Results}

Cincticostella tornata Auychinda \& Gattolliat, sp. nov. http://zoobank.org/8230C5FE-CB09-4C40-AAD6-E163C6AC9986

Material. Holotype: China • Larva; Shaanxi, Hanzhong city, Foping county, Qinling Mts, slow forest brook in Panda valley; Alt. $1330 \mathrm{~m}$. $33^{\circ} 40.368^{\prime} \mathrm{N}, 107^{\circ} 58.327^{\prime} \mathrm{E}$; 20 Apr. 2018; Coll. W.H. Li, R.R. Mo, D. Murányi; MZL GBIFCH 00763636.

Paratypes: China -5 larvae; same data as for holotype; 2L in alcohol GBIFCH 00673084; 1L on slide GBIFCH 00606852; 1L on slide used for DNA extraction GBIFCH 00654874 all deposited in MZL. 1L in alcohol deposited in HNHM. 1L in alcohol deposited in HIST.

Description. Larva: Body length $8.7-10.0 \mathrm{~mm}$; caudal filaments length $8.0-9.0 \mathrm{~mm}$. Body yellowish-brown.

Head: Covered with thin setae. One pair of small, rounded protuberances between eyes. Genae quadrangular, well developed, angles rounded (Fig. 1). Antennae with scapus short, pedicellus as broad as long, flagellum of about 25 segments, first segment as long as next three segments.

Mouthparts: Labrum wide, apicolateral angle rounded; apicomedial emargination shallow, dorsal surface densely covered with long, hair-like setae and long stout flattened setae scattered over surface (Fig. 2A); ventral surface with numerous, long, stout, hair-like setae laterally orientated; apical margin with numerous feathered setae and very thin hair-like setae (Fig. 2B). Mandibles with numerous, hairlike setae on $2 / 3$ proximal of dorsal and lateral surfaces (Figs 2C, D). Left mandible: outer incisor composed of 

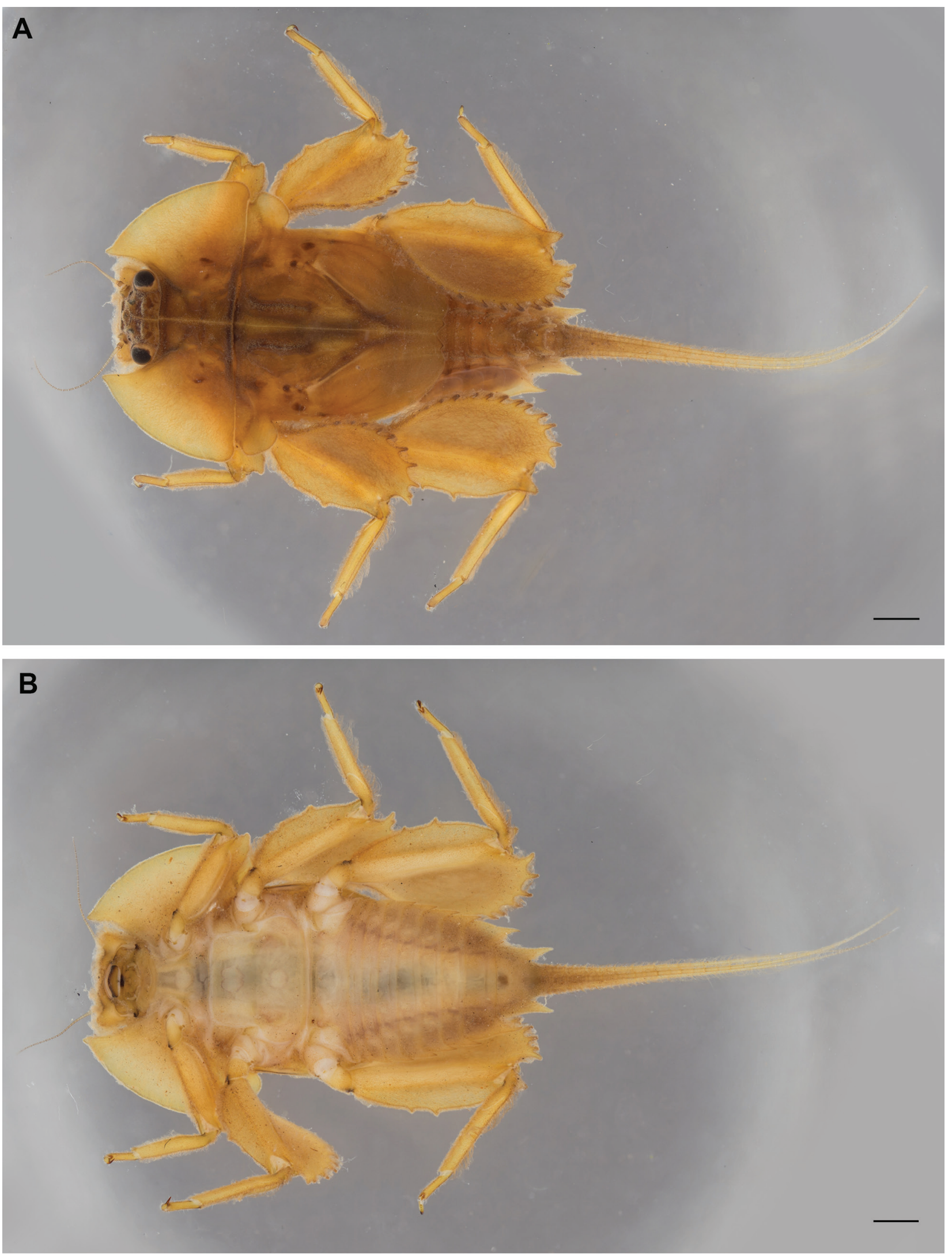

Figure 1. Cincticostella tornata: A habitus in dorsal view; B habitus in ventral view. Scale bar: $1 \mathrm{~mm}$.

three teeth, two outer teeth stout, broad, apically rounded and one small, blunt tooth; inner incisor with one main stout, apically pointed tooth and one inner vestigial tooth; stout rectangular prostheca with bunch of hair-like setae on inner side (Fig. 2E). Right mandible: outer incisor composed of two spoon-shaped teeth, outer tooth longer 

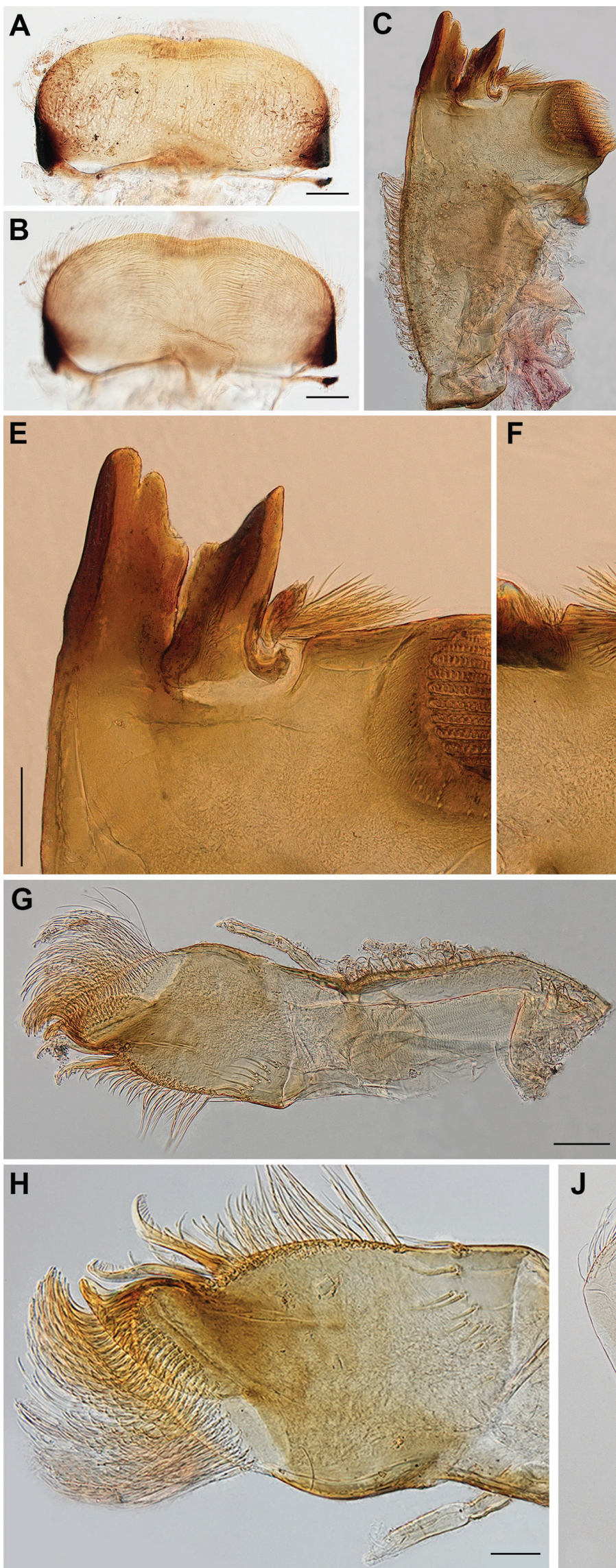

J
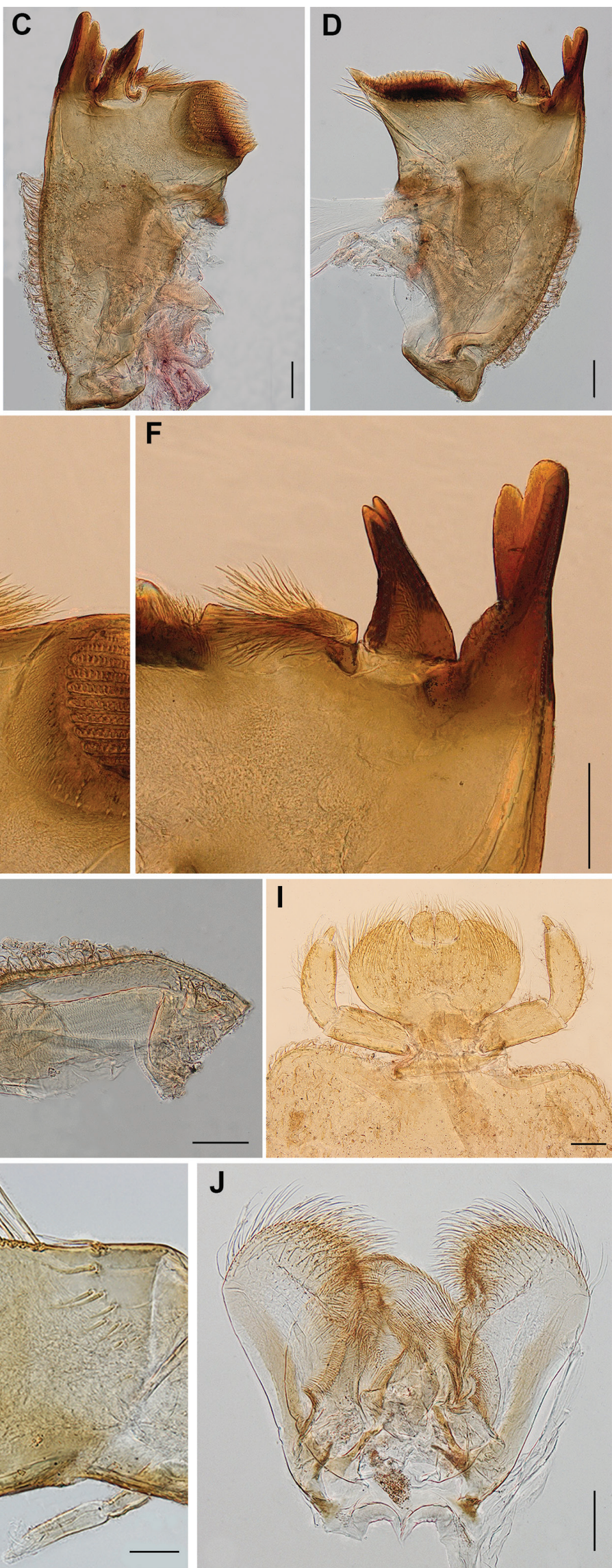

Figure 2. Cincticostella tornata: A dorsal view of labrum; B ventral view of labrum; $\mathbf{C}$ left mandible; $\mathbf{D}$ right mandible; $\mathbf{E}$ left mandibular canine; $\mathbf{F}$ right mandibular canine; $\mathbf{G}$ maxilla; $\mathbf{H}$ crown of maxilla; I labium; $\mathbf{J}$ hypopharynx. Scale bars: $0.1 \mathrm{~mm}$ (A-D, G-I, J); 0.05 mm (E, F, H). 
than inner; inner incisor composed of two apically pointed teeth, orientated perpendicularly to outer incisor; prostheca consisting of numerous hair-like setae (Fig. 2F); eight hair-like setae on margin below mola (Fig. 2D). Maxilla: apex with transformed ventral canine typical of genus (Kluge 2004); two dentisetae with serrated inner margin; apex of maxilla surface with numerous, long, stout, hairlike setae, some with serrated inner margin; inner margin of galealacinia with 3-4 rows of long, stout, simple setae; 10-12 feathered, stout setae roughly arranged in a row near base of galealacinia surface (Fig. 2G, H). Maxillary palp: three segmented; segments partially fused; segment I slightly longer than half of segments II and III combined; segment III short, pointed, with few thin setae on apex (Fig. 2G, H). Labium with glossae semicircular, almost two times longer than broad; ventral surface of glossae covered with long, stout, simple setae; dorsal surface with an arc of long simple setae parallel to outer margin; glossae protruding over apices of paraglossae; paraglossae semicircular, dorsal surface covered with numerous long stout simple setae, ventral surface with flame-like setae. Ventral surface of mentum and submentum mostly covered with flame-like setae. Labial palp three-segmented; segments I and II equal in length, covered with long, hairlike setae; segment II crescent shaped, outer margin with spine-like long setae and long hair-like setae, inner margin covered with numerous long thin setae; segment III conical, two times longer than broad at base, apex covered with short thin setae (Fig. 2I). Hypopharynx: surface of lingua covered with short setae, most abundant in apical part; apices of superlinguae rounded with numerous hairlike setae (Fig. 2J).

Thorax: dorsal surface covered with scattered small thin setae. Pronotum: broad projection anterolaterally enclosing head, margin rounded except concave apically (black arrow tip on Fig. 3A); projections covered with long hair-like setae; laterally with short flame-like setae. Mesonotum: broad, large, rounded anterolateral projection, covered with long hair-like setae; laterally with short flame-like setae; small pair of triangular protuberances between forewing pads (white arrow tips on Fig. 3A). Forelegs: moderately expanded; length ratio of femur : tibia : tarsus $=2.9: 2.4: 1$. Forefemora: dorsal surfaces cover with long hair-like setae; dorsal margin slightly concave, with dense setae and with only three blunt chalazae near distal angle; ventral margin with dense setae without serration; apex with one ventral and one dorsal well-developed extension (Fig. 4A). Foretibiae completely covered with long hair-like setae and short stout setae, apex of ventral margin produced and covered with a bunch of dense, long, thin setae. Foretarsi covered with long hair-like setae, ventral margin with stouter longer feathered setae. Foreclaws hooked with a row of four triangular teeth, two proximal teeth closer to each others (Fig. 4D). Mid legs: greatly expanded; length ratio of femur : tibia : tarsus $=3: 2.7: 1$. Mid femora: dorsal surface cover with hair-like setae; ventral margin with dense setae and four serrated chalazae in proximal half of femora, ending with a well-developed triangular pointed process; dorsal margin with dense setae and eight chalazae progressively larger (Fig. 4B). Mid tibiae similar to foretibiae except setae less abundant and short flame-like setae on dorsal margin and apically. Mid tarsi: ventral margin with setae not feathered. Mid claws similar to foreclaws. Hind legs: greatly expanded; length ratio of femur : tibia : tarsus $=4.2: 3.2: 1$; hind femora similar to mid femora except chalazae of ventral and dorsal margins: ventral margin with three chalazae medially; dorsal margin with 12 chalazae along margin and progressively larger (Fig. $4 C$ ). Hind tibiae and hind tarsi similar to mid tibiae and mid tarsi, respectively. Hind claws similar to foreclaws.

Abdomen: surface of tergites covered with hair-like setae and few stout flame-like setae, absent laterally on tergites IV to IX; distal margin smooth without spines. Tergites I-X with a pair of tubercles, minute on tergites I-III and X (Fig. 4E); highly developed on tergites IV-IX (Fig. 3B): arched, acute tubercles covered with medium setae (Fig. 3C). Sternites densely covered with medium setae; distal margin smooth without spines. Triangular, slender distolateral expansions present on abdominal segments I to IX, highly developed on segments IV to IX, covered with dense flat medium and hair-like setae. Gills present on segments III to VII (Fig. 3E-I); upper lamellae dorsally densely covered with flame-like setae, upper lamellae of gills III to V subrectangular, of gills VI roughly paddle-like, of gills VII suboval and reduced; lower lamellae bifurcate with marginal processes, bilobed on gills III to V, simple on gills VI and VII. Paracercus subequal in length to cerci; cerci and paracercus densely covered with hair-like setae, apex of each segment with very long, flattened setae (Fig. 3D).

Adults. Unknown.

Etymology. The Latin word "tornata" means rounded, in reference to the genae and anterolateral projection of mesonotum.

Diagnosis. Cincticostella tornata sp. nov. differs from closely related species of the insolta-group by the following combination of characters: 1) glossae protruded beyond apices of paraglossae; 2) genae extended with round apex; 3) anterolateral projection of pronotum pointed with a concave margin; 4) mesothorax with broad, rounded proximolateral expansion; 5) number and degree of development of chalazae on ventral and dorsal margins of mid and hind femora; 6) degree of development of apicoventral projection on ventral margin of fore-, mid and hind femora; 7) apicolateral projection of tergite IX well developed exceeding $1 / 3$ of tergite $X$.

Distribution. The new species is only known from the type locality located in the Qinling mountains (Shaanxi province, close to Hanzhong city). This mountain range is considered as a natural boundary between South and North China and between the Palaearctic and Oriental realms (Fig. 5). A huge diversity of plant and animals is considered as endemic from this area, among others a subspecies of the giant panda (Ailuropoda melanoleuca qinlingensis) and the golden snub-nosed monkey 

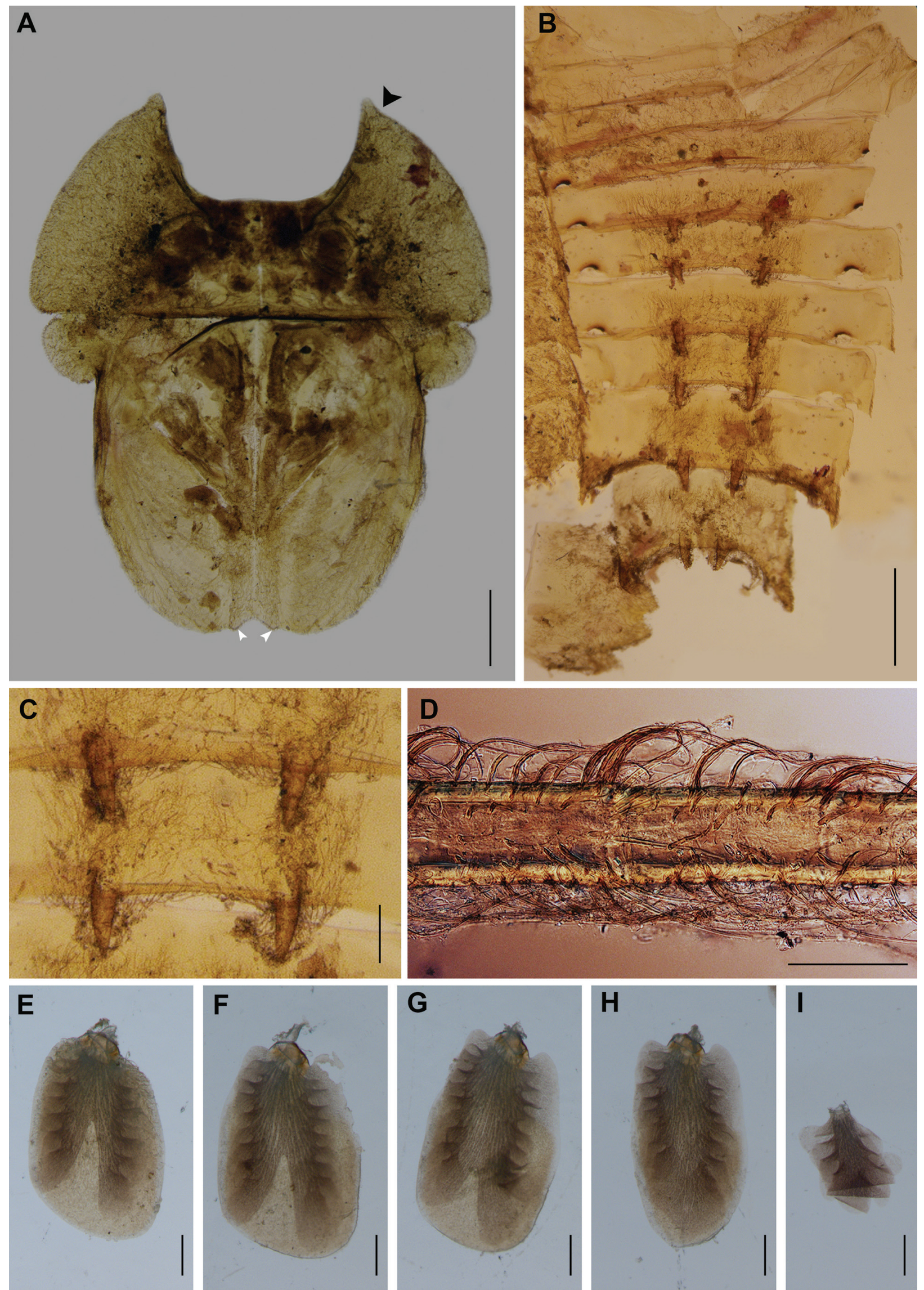

Figure 3. Cincticostella tornata: A thorax (black arrow tip: concave apical margin of prothorax; white arrow tips: small pair of triangular protuberances between forewing pads); B abdomen; C tergites VI-VII; D cercus; E-I gills of segments III-VII respectively. Scale bars: $1 \mathrm{~mm}(\mathrm{~A}, \mathrm{~B}) ; 0.25 \mathrm{~mm}(\mathrm{C}-\mathrm{I})$. 
A

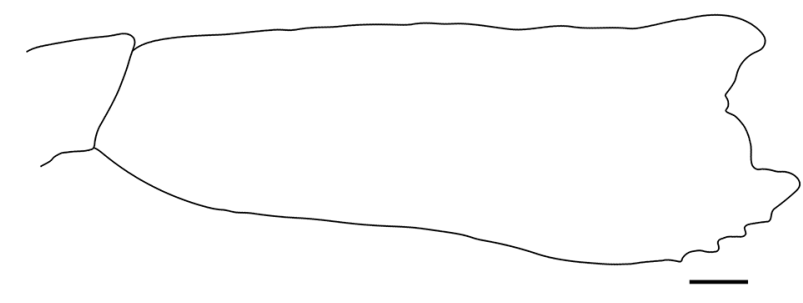

C

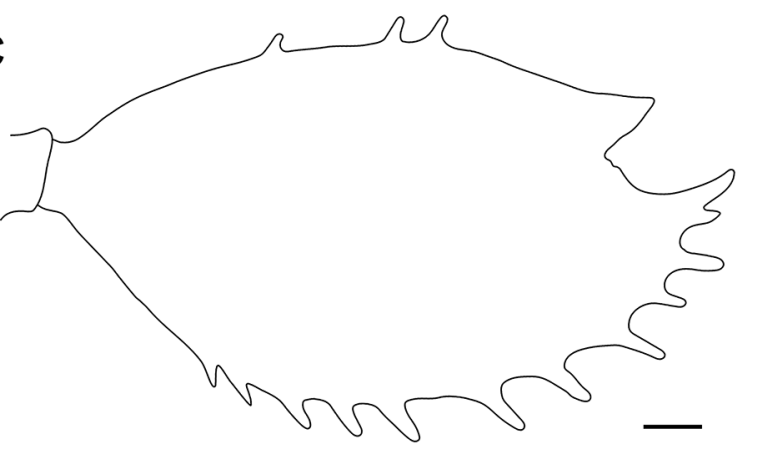

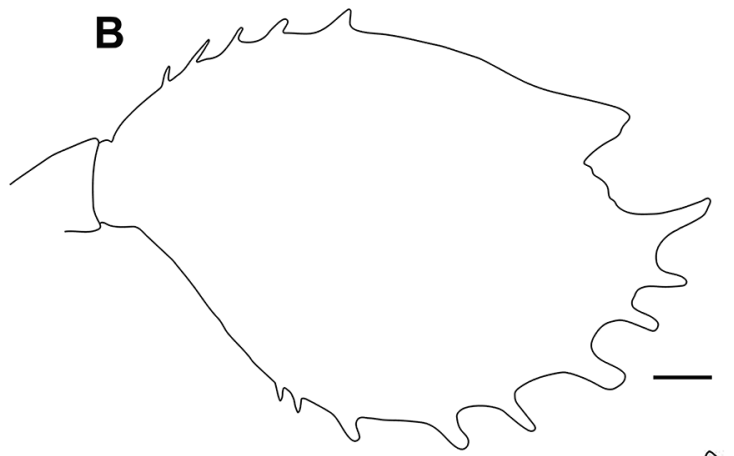

D

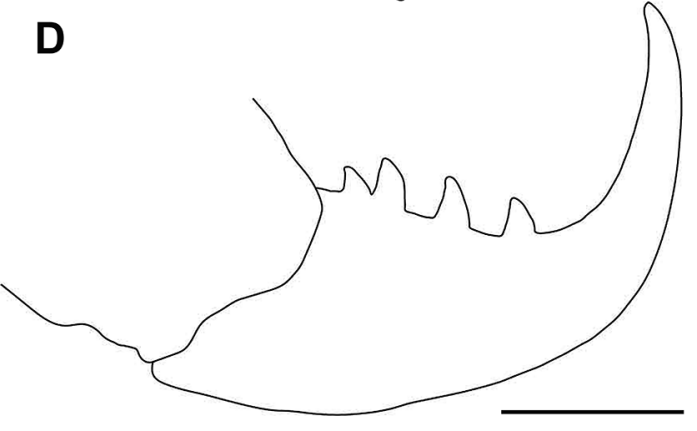

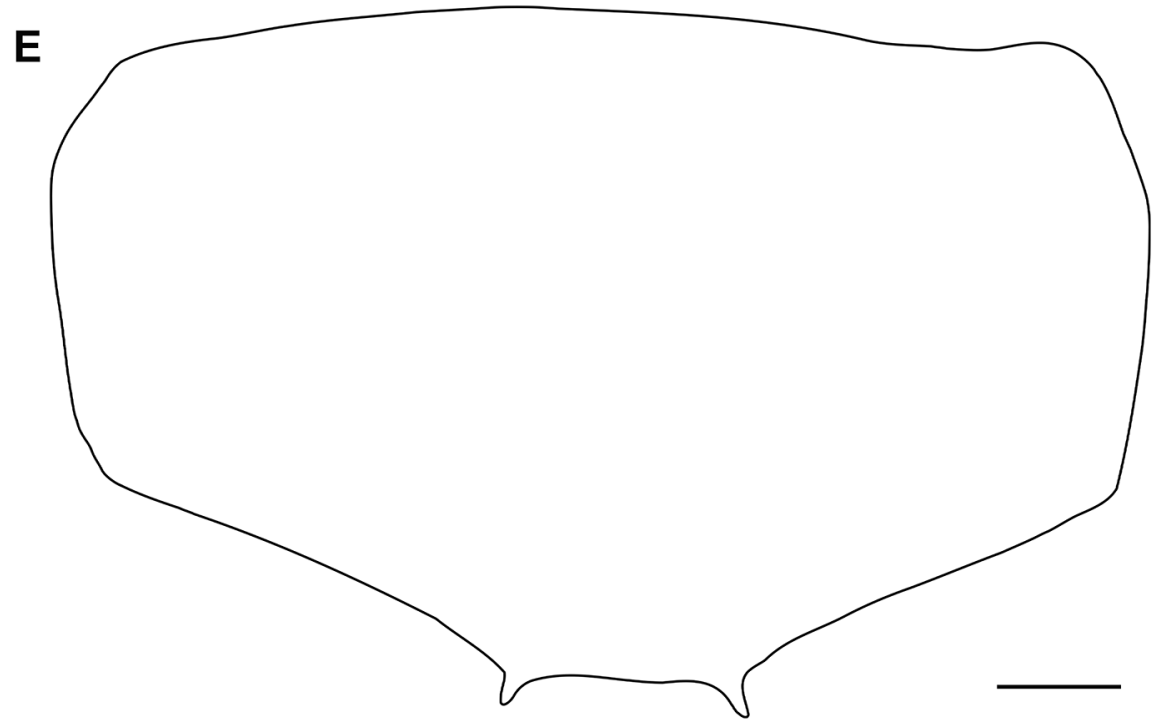

Figure 4. Cincticostella tornata: A forefemur; B mid femur; C hind femur; D forefemur claw; E tergite X. Scale bars: $0.2 \mathrm{~mm}$ (A-C); $0.1 \mathrm{~mm}(\mathrm{D}, \mathrm{E})$.

(Rhinopithecus roxellana). At our present state of knowledge, it is not possible to know if Cincticostella tornata sp. nov. is endemic to this mountain range or is more widely distributed through China.

Habitat. The larvae were found in a small forest brook of relatively slow current. Maximum width of the brook is about 1.5 meter; depth varies between 10 and 30 centimetres. The substrate is mostly stony and sandy, mixed with silty patches and a moderate amount of debris. Accompanying fauna included two Holarctic genera of mayflies, Baetis (Baetidae) and Ameletus (Ameletidae), as well as the stoneflies Rhopalopsole basinigra Yang \& Yang, 1995, Spaeronemoura grandicauda (Wu, 1973), Nemou$r a \mathrm{sp}$., and two species recently described from the same area, namely Amphinemura albicauda Li, Mo, Dong, Yang \& Murányi, 2018 and Amphinemura dingoidea Li, Mo, Dong, Yang \& Murányi, 2018 (Li et al. 2018).

Molecular results. A sequence of $658 \mathrm{bp}$, corresponding to the usual fragment of the COI gene, was obtained. The sequence was deposited in GenBank (Accession number: MT254050). It was compared to other known sequences found in databases such as GenBank and BOLD. The closest sequence corresponds to a North America Ephemerellidae (Drunella walker (Eaton, 1884)) with less than $83 \%$ of identity. Around twenty sequences were found with a percentage of identity comprising between 80 and 83 , most of them belonging to the families Ephemerellidae and Caenidae. K2P distance 


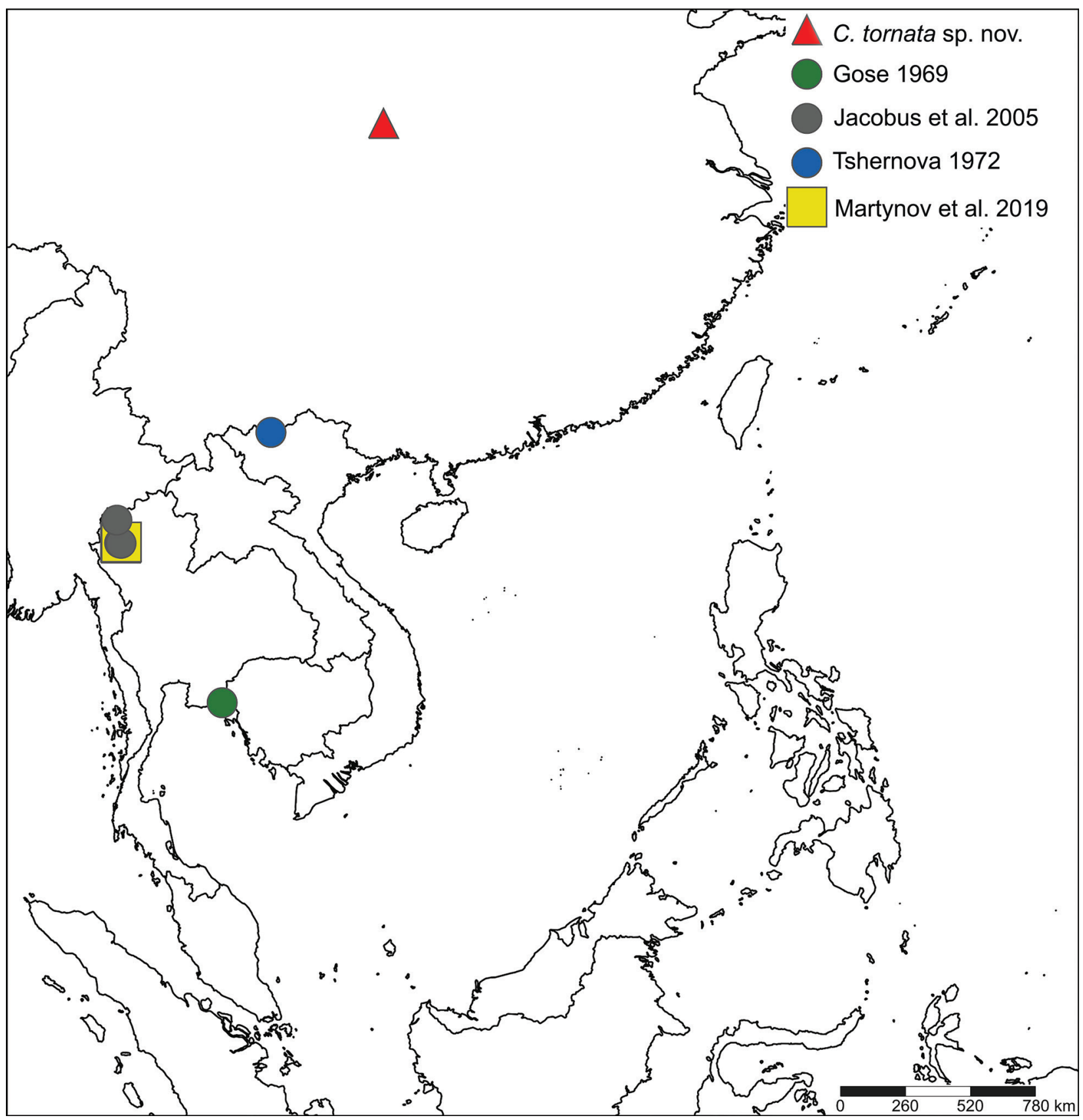

Figure 5. Map distribution of C. femorata and C. tornata. C. femorata represented by green circle (Gose 1969), blue circle (Tshernova 1972), gray circle (Jacobus 2005) and yellow square (Martynov et al. 2019); C. tornata represented by red triangular. Localities of C. femorata in China are not reported on the map as the species was mentioned from China by Xie et al. 2009 but without further information.

was also calculated with a sequence of Cincticostella gosei from Thailand (collected and sequenced by the first author, GenBank accession number: MN186574.1). The distance between the two species was estimated to $21.6 \%$ (meaning only $78.4 \%$ of identity).

\section{Discussion}

Within the insolta-group, C. femorata and C. tornata share two presumably derived characters, namely the anterolateral expanded prothorax and the extremely flattened mid and hind femora. The degree of development, the position and the orientation of the tubercles on the abdominal tergites of $C$. tornata are different from other species of the group. However, these characters must be considered with caution as it was recently demonstrated in a species of Notacanthella Jacobus and McCafferty, 2008. Two morphotypes were present based on the shapes of the tubercles, but these intraspecific variabilities mainly correspond to different ontogenic stages (earlier stages having more prominent tubercles) 
Table 1. Larval character comparisons of C. femorata and C. tornata.

\begin{tabular}{|c|c|c|c|c|}
\hline Characters & $\begin{array}{c}\text { C. femorata } \\
\text { (Tshernova 1972) }\end{array}$ & \begin{tabular}{|c|} 
C. femorata (Martynov \\
2019)
\end{tabular} & $\begin{array}{l}\text { C. femorata = C. boja } \\
\text { (Gose 1969) }\end{array}$ & Cincticostella tornata sp. nov. \\
\hline Labium & $\begin{array}{c}\text { Glossae not protruding } \\
\text { beyond paraglossae }\end{array}$ & - & $\begin{array}{c}\text { Glossae not protruding } \\
\text { beyond paraglossae }\end{array}$ & $\begin{array}{c}\text { Glossae protruding beyond } \\
\text { paraglossae }\end{array}$ \\
\hline Maxillary canine & $\begin{array}{c}\text { Well-developed, sharp, } \\
\text { conical }\end{array}$ & - & $\begin{array}{c}\text { Reduced, length less } \\
\text { than width }\end{array}$ & $\begin{array}{c}\text { Reduced, length less than } \\
\text { width }\end{array}$ \\
\hline $\begin{array}{l}\text { Chalazae: dorsal/ } \\
\text { ventral margin of } \\
\text { forefemora }\end{array}$ & 3/none & 3/none & None/none & 3/none \\
\hline $\begin{array}{l}\text { Chalazae: dorsal/ } \\
\text { ventral margin of } \\
\text { mid femur }\end{array}$ & 4/none & 9/none & $7 / 3$ & $9 / 6$ \\
\hline $\begin{array}{l}\text { Chalazae: dorsal/ } \\
\text { ventral margin of } \\
\text { hind femur }\end{array}$ & $11 /$ none & 9/none & $11 / 5$ & $12 / 4$ \\
\hline $\begin{array}{l}\text { Anterolateral } \\
\text { projection of } \\
\text { pronotum }\end{array}$ & $\begin{array}{l}\text { Broad, apically blunt, } \\
\text { convex below tip }\end{array}$ & $\begin{array}{l}\text { Broad, apically blunt, } \\
\text { convex below tip }\end{array}$ & $\begin{array}{c}\text { Broad, apically } \\
\text { pointed, concave } \\
\text { below tip }\end{array}$ & $\begin{array}{l}\text { Broad, apically pointed, } \\
\text { concave below tip }\end{array}$ \\
\hline Claws & $\begin{array}{c}\text { Somewhat hooked, } 2 \\
\text { small teeth }\end{array}$ & - & $\begin{array}{l}\text { Somewhat hooked, } \\
\text { 3-4 small teeth }\end{array}$ & Hooked, 4 teeth \\
\hline Genae & $\begin{array}{l}\text { Extended with a } \\
\text { rounded apex }\end{array}$ & $\begin{array}{l}\text { Extended with a } \\
\text { rounded apex }\end{array}$ & $\begin{array}{c}\text { Extended, with a little } \\
\text { corner }\end{array}$ & Extended with a rounded apex \\
\hline $\begin{array}{l}\text { Prostheca right } \\
\text { mandible }\end{array}$ & - & - & $\begin{array}{l}\text { Well-developed with a } \\
\text { bunch of simple setae }\end{array}$ & $\begin{array}{l}\text { Reduced with a bunch of } \\
\text { simple setae }\end{array}$ \\
\hline $\begin{array}{l}\text { Prostheca left } \\
\text { mandible }\end{array}$ & $\begin{array}{l}\text { Well-developed, } \\
\text { conical with a bunch } \\
\text { of simple setae }\end{array}$ & - & $\begin{array}{l}\text { Well-developed, } \\
\text { slender with a bunch } \\
\text { of simple setae }\end{array}$ & $\begin{array}{l}\text { Well-developed, rounded with a } \\
\text { bunch of simple setae }\end{array}$ \\
\hline $\begin{array}{l}\text { Posterolateral } \\
\text { projection of } \\
\text { abdominal tergites }\end{array}$ & IV-IX & $I I I-X$ & $11-X$ & $1-X$ \\
\hline $\begin{array}{l}\text { Lateral projection } \\
\text { of tergite IX }\end{array}$ & $\begin{array}{c}\text { Moderately developed, } \\
\text { not extended beyond } \\
\text { tergite } X\end{array}$ & $\begin{array}{l}\text { Well-developed, } \\
\text { extended beyond } \\
\text { tergite X }\end{array}$ & $\begin{array}{l}\text { Well-developed } \\
\text { extended equally } \\
\text { tergite } X\end{array}$ & $\begin{array}{c}\text { Well-developed extended } \\
\text { beyond tergite } X\end{array}$ \\
\hline Cerci & $\begin{array}{l}\text { High density of long } \\
\text { hair-like setae }\end{array}$ & - & $\begin{array}{l}\text { Low density of short } \\
\text { hair-like setae }\end{array}$ & $\begin{array}{l}\text { Low density of medium hair- } \\
\text { like setae }\end{array}$ \\
\hline $\begin{array}{l}\text { Small occipital } \\
\text { spines on head }\end{array}$ & Present & - & Present & Present \\
\hline Distribution & Vietnam & Thailand & Thailand & China \\
\hline
\end{tabular}

(Auychinda et al. 2020). As already mentioned, C. femorata and $C$. tornata only differ by minute characters which may be easily overlooked. In particular, when using the keys to identify species of Cincticostella (Allen 1975; Xie et al. 2009), one will arrive to C. femorata without discrepancies. This easily explains why all the larvae with expanded prothorax, flattened femora and developed genae were previously identified as C. femorata. A global revision involving all available material from South East Asia is highly recommended for the species delimitation of $C$. femorata, including the confirmation or rejection of the synonymy of $C$. boja with $C$. femorata as well as the correct attribution of the material from South and Central China to one of these species. This revision should be ideally based on integrative taxonomy, especially by using both morphological and molecular evidences. The comparison of the characters in the closely related species is summarized in Table 1. Noteworthy, the imagos all these taxa remain unknown. The recent discovery and description of imaginal C. fus$c a$ revealed that male genitalia (penes and gonopods), tergite pattern and pigmentation of hind wings are re- liable characters to distinguish the different species of Cincticostella (Zhang et al. 2020). We may expect that imaginal characters will confirm the separation and validity of these closely related species.

The type-locality of $C$. tornata is located $1200 \mathrm{~km}$ north to those of $C$. femorata and $2350 \mathrm{~km}$ north to those of $C$. boja (1700 km north to the closest report from Thailand) (Martynov et al. 2019). These long distances may explain the differences observed between taxa and may be the results of vicariant speciation. Xie et al. (2009) indicated that Cincticostella species were frequently collected in the recent years (meaning probably during the first decade of this century). However, they did not indicate where in China C. femorata was found and how widespread the species is. It will be of first interest from a biogeographic point of view to properly identify this material. This will allow the clarification of the distribution of C. femorata in China and may also clarify the distribution of $C$. tornata. It is also not excluded that collected specimens mentioned by Xie et al. (2009) partly belong to C. tornata or even to a still undescribed species. 


\section{Acknowledgements}

This research was made possible by facilities and assistances of Museum of Zoology, Lausanne, Switzerland to the first author. We are most grateful to Assoc. Prof. Dr Boonsatien Boonsoong and our colleagues for assistance during the stay of the first author in Lausanne. CA would like to thank the Development and Promotion for Science and Technology talents project (DPST) for a short-term research scholarship in the MZL. We thank Marion Podolak for providing the molecular sequence. We want to sincerely thank Arnold Staniczek and Erikcsen Raimundi for their valuable comments on the manuscript.

\section{References}

Allen RK (1971) New Asian Ephemerella with notes (Ephemeroptera: Ephemerellidae). The Canadian Entomologist 103: 512-528. https:// doi.org/10.4039/Ent103512-4

Allen RK (1975) Ephemerella (Cincticostella): a revision of the nymphal stages (Ephemeroptera: Ephemerellidae). The Pan-Pacific Entomologist 51: 16-22.

Allen RK (1980) Geographic distribution and reclassification of the subfamily Ephemerellinae (Ephemeroptera: Ephemerellidae). In: Flannagan JF, Marshall KE (Eds) Advances in Ephemeroptera Biology. Plenum Press, New York, 71-92. https://doi.org/10.1007/9781-4613-3066-0_6

Auychinda C, Sartori M, Boonsoong B (2020) Review of Notacanthella Jacobus \& McCafferty, 2008 (Ephemeroptera: Ephemerellidae) in Thailand, with the redescription of Notacanthella commodema (Allen, 1971). Zootaxa 4731: 414-424. https://doi.org/10.11646/ zootaxa.4731.3.9

Folmer O, Black M, Hoeh W, Lutz R, Vrijenhoek R (1994) DNA primers for amplification of mitochondrial cytochrome $\mathrm{C}$ oxidase subunit I from diverse metazoan invertebrates. Molecular Marine Biology and Biotechnology 3: 294-299.

Gose K (1969) Mayflies (Ephemeroptera) from Thailand. Nature and Life in Southeast Asia 6: 125-138.

Jacobus LM, McCafferty WP (2008) Revision of Ephemerellidae genera (Ephemeroptera). Transactions of the American Entomological
Society 134: 185-274. https://doi.org/10.3157/0002-8320(2008)13 4[185:ROEGE]2.0.CO;2

Jacobus LM, McCafferty WP, Sites RW (2005) A new synonym and new Thailand records of Cincticostella femorata (Tshernova) (Ephemeroptera : Ephemerellidae). Proceedings of the Entomological Society of Washington 107: 733-734.

Kluge NJ (2004) The phylogenetic system of Ephemeroptera. Kluwer Academic Publishers, Dordrecht, 442 pp. https://doi. org/10.1007/978-94-007-0872-3

Kluge NJ (2019) Ephemeroptera of the World. http://www.insecta.bio. spbu.ru/z/Eph-spp/Contents.htm [accessed 10.12.2019]

Kumar S, Stecher G, Tamura K (2016) MEGA7: Molecular Evolutionary Genetics Analysis. Ver. 7. for Bigger Datasets. Molecular Biology and Evolution 33: 1870-1874. https://doi.org/10.1093/ molbev/msw054

Li WH, Mo RR, Dong WB, Yang D, Murányi D (2018) Two new species of Amphinemura (Plecoptera, Nemouridae) from the southern Qinling Mountains of China, based on male, female and larvae. ZooKeys 808: 1-21. https://doi.org/10.3897/zookeys.808.29433

Martynov AV, Selvakumar C, Subramanian KA, Sivaramakrishnan KG, Chandra K, Palatov DM, Sinha B, Jacobus LM (2019) Review of the Cincticostella insolta (Allen, 1971) complex (Ephemeroptera: Ephemerellidae), with description of three new species from northern India and Nepal. Zootaxa 4551: 147-179. https://doi. org/10.11646/zootaxa.4551.2.2

Tshernova OA (1972) [Some new species of may-flies from Asia (Ephemeroptera, Heptageniidae, Ephemerellidae)] (in Russian). Entomologichekoye Obozrenie 51: 604-614.

Vuataz L, Sartori M, Wagner A, Monaghan MT (2011) Toward a DNA Taxonomy of Alpine Rhithrogena (Ephemeroptera: Heptageniidae) Using a Mixed Yule-Coalescent Analysis of Mitochondrial and Nuclear DNA. Plos One 6. https://doi.org/10.1371/journal. pone.0019728

Xie H, Jia YY, Chen P, Jacobus LM, Zhou CF (2009) Two new Cincticostella species from China with a larval key to species of the genus (Ephemeroptera: Ephemerellidae). Zootaxa 2299: 53-61. https:// doi.org/10.11646/zootaxa.2299.1.5

Zhang W, Han N, Zhang M, Wang YF, Zhou CF (2020) The imaginal and detailed nymphal characters of Cincticostella fusca with note on ecology (Ephemeroptera: Ephemerellidae). Zootaxa 4729: 277-285. https://doi.org/10.11646/zootaxa.4729.2.8 